Training and Research Grants

ON April 1, 2,648 training awards of the Depart. ment were currently hold, of which a small number are being held overseas; of those held in Great Britain, 10.1 per cent were held in Scotland. Of 724 grants for special researches awarded in the year ended September $30,1961,81$ were in response to applications from Scotland.

\section{Scientific Manpower}

Concerning manpower, Mr. Freeth reported that the third triennial survey of scientific manpower is in progress, and in the course of this the Committee on Seientific Manpower will be able to take into account any changes in the estimated output of the universities since its last review. The Department of Technical Co-operation obtains advice on scientific matters from a wide range of experts, including scientists from the Department of Scientific and Industrial Research and the Nature Conservancy. An important way in which this advice is provided is by making the staff of these organizations available for membership of advisory committees of the Department of Technical Co-operation.

\section{Promoting Civil Science}

Mr. Freerth said that a Committee had been set up under the chairmanship of Mr. B. St. J. Trend to review the organization for the promotion of civil science by Government agencies. The other members of the Committee are: Sir Keith Murray, Sir Thomas Padmore, Lord Todd, Mr. F. F. Turnbull, Prof. C. H. Waddington and Dr. E. G. Woodroofe, with Miss K. Whalley as secretary. The terms of reference are to consider: ( 1 ) whether any changes are desirable in the existing functions of the various agencies, for which the Minister for Science is responsible, concerned with the formulation of civil scientific research, and whether any new agencies would be created for these purposes; (2) what arrangements should be made for determining, with appropriate scientific advice, the relative importance in the national interest of the claims on the Exchequer for the promotion of civil scientific research in the various fields concerned; and (3) whether any changes are needed in the existing procedure whereby the agencies concerned are financed and required to account for their expenditure.

Industry and Space Research

IN a written answor on May 28, Mr. Freeth statod that British industry will continue to benefit from work carried out under contracts for the development and construction of experimental equipment for use in scientific space resoarch and also for the development and construction of satellite launchers. The technological benefits to be derived from this work will strengthen the compctitive power of British industry, particularly in electronics and the technology of new materials. It was proposed to hold an inter-governmental confercnce in the middle of June, at which tho European Space Research Organization Convention and its associated protocols would be open for signature.

\section{D.S.I.R. Developments}

BoTy branch offices of the Department of Scientific and Industrial Rosearch in Edinburgh and Cardiff have been strengthened recently, and six regional technical information centres are now operating, in
Newcastle, Liverpool, Manchester, Birmingham, Bristol and Portsmouth. A seventh is being established in Leeds.

\section{The Esso Review}

The Esso Review for 1961 is a model of how a big company can present information about its activities for the benefit of its employees scattered in many countries. The growth of the oil industry is well described in pictorial form and shows how world crude oil production reached a total of 1,120 million tons, some 70 million tons more than in 1960. This 6.5 per cent increase was only slightly less than the average growth-rate of the past ten years, the outlook being for continued growth. The Middle East produced as much oil in 1961 as was produced in the whole world in 1939. In Europe, the increase in oil consumption was particularly marked, although the rate of growth in the United Kingdom was less than the European average. The Review shows that United Kingdom energy demand was about the same in 1961 as in 1960 because of the small rise in economic activity and above-average temperatures, but that demand for oil in the Unitod Kingdom rose by about 7 per cent and oil contributed 27 per cent of the total energy needs. There are also many illus. trations of Esso's activities inside Great Britain, including the construction of the pipeline from Fawley to Severnside.

\section{Canadian National Parks}

The Goological Survey of Canada has issued two attractive brochures describing various geological features of two Canadian national parks (Miscellaneous Report No. 2: Rocks and Scenery of Fundy National Park. Pp. iii +32. Ottawa: Queen's Printer, 1962. 50 cents. Miscellaneous Report No. 3: Prince Edward Island National Park-The Living Sands. Pp. 56. Ottawa: Queen's Printer, 1961. 50 cents). They have been written by David M. Baird, who, in the first, explains the part played by the rocks of Fundy National Park in determining its scenery. In the second brochure he shows how the waves of the Gulf of St. Lawrence have evened out the irregular lines of the north shore of Prince Edward Island to form long sandy beaches and bars across the headlands and the mouths of bays; the latter have been set aside as the Prince Edward National Park. Both brochures are illustrated and add to the value of well-written publications which should give pleasure to many visitors to the parks.

\section{Birds Around Winchester}

A sHORT account of the birds of the Winchester district has been prepared from the records of the Winchester College Natural History Society during the past ten years (Birds of the Winchester District. Pp. 39 (5 maps). Winchester: Winchester College Natural History Society, 1962. 5s.). The gaps in observations resulting from school holidays, particularly those relating to the early migrants, have been largely filled from the records of the Hampshire Field Club and Archæological Society. The publication is not intended to be a guide to bird identification. Rather it is an attempt to bring together, within a small compass, information about birds to be found at different times of the year within a ten-mile radius of Winchester. The various maps included with the text are sufficiently detailed for the identi. fication of most of the bird habitats described. The School's Naturnl History Society is to be commended 